International Research Journal of Management, IT \& Social Sciences
Available online at https://sloap.org/journals/index.php/irjmis/
Vol. 9 No. 1, January 2022, pages: 181-192
ISSN: 2395-7492
https://doi.org/10.21744/irjmis.v9n1.2041

\title{
Factors Affecting the Implementation of the Village Development Plan Deliberation (Musrembang) in Waeheru Village, Teluk Ambon District, Ambon City
}

$\begin{array}{r}\text { Q CrossMark } \\ \begin{array}{r}\text { Nurainy Latuconsina }^{\text {a }} \\ \text { Atikah Khairunnisa } \\ { }^{b} \\ \text { Johan Tehuayo }^{c}\end{array} \\ \hline\end{array}$

Article history:

Submitted: 27 November 2021

Revised: 09 December 2021

Accepted: 18 January 2022

\section{Keywords:}

deliberation;

development;

implementation;

participation;

planning;

\begin{abstract}
Community empowerment is the implementation of village government that realizes the community's active role to be responsible for the development of shared life. This phenomenon sometimes illustrates that planning does not involve community stakeholders in formulating development policies. Planning errors carried out in the field often cannot be implemented; this happens because the paradigm of thinking of the bureaucratic apparatus is attached to various forms of interests that cannot be separated. One form of reference that can be put forward here is the mechanism for deliberation on development planning. Musrenbangdes is a mechanism in determining development policies and programs that must involve stakeholders. Sometimes it does not describe the form of a forum that can accommodate all the community's aspirations. Communities that exist as stakeholders are often ignored so that the screening of community aspirations does not work well. For example, local organizations such as the SOA adat group, hamlet, RT, and community units are rarely involved in the Musrenbang mechanism at the local level. The problem is that the society that forms the dynamics of this interest is a collection of individuals who tend to be adaptive, who maintain sociocultural values.
\end{abstract}

International research journal of management, IT and social sciences (C) 2022. This is an open access article under the CC BY-NC-ND license (https://creativecommons.org/licenses/by-nc-nd/4.0/).

Corresponding author:

Nurainy Latuconsina,

Pattimura University, Indonesia

Email address: nurainy.latuconsina123@gmail.com

\footnotetext{
Pattimura University, Indonesia

Pattimura University, Indonesia

Pattimura University, Indonesia
} 


\section{Introduction}

The development planning process that occurs in village communities can run dynamically and sustainably to realize a desire and hope for a more prosperous life with a strategy to avoid the possibility of being cornered by the community as access to regional/regional development (Hidayat, 2003), the symptoms found in Waiheru village are; Implications uninvolved stakeholders (stakeholders) in a planning process of rural development especially in rural Waiheru Baguala Teluk Ambon Ambon City based on direct observation in the field. The problem that occurs describes that the community as stakeholders is not optimally accommodated in the village development planning process; it can be seen that the community does not give their voting rights as community members responsible for a development plan discussed in village meetings (Van Lier, 1998; Pickett et al., 2004). Implementing the organizational policy partnership concept is a factor in implementing government organizational programs (Tuanaya \& Wance, 2021).

One of the contributing factors is that the community's rights as thinkers of deliberation, planners, implementers, and supervision are always ignored so that a village development planning process does not answer the needs of the community (Wilson \& Howarth, 2002). This is what the people of Waiheru Village always face. This happens because; 1) The village's development approach and planning process are mainly carried out individually (village head/king) and a group of interests; for example, several people from the BPD and village staff are considered to be accommodated/close to the village head. As a result, the public space given to the community is limited in the village deliberation process (Spash, 2007). So that access restrictions occur in the decision-making process because so far what has happened is that the mobilization of community participation in the development planning process is very weak, such as pluralistic development participation due to the design of development programs only unilaterally, so that it can answer the needs of the community. 2) On the other hand, the condition of Waiheru Village with a very diverse population level is also a problem in itself in the development process; for example, there is an assumption that the decision-making process that can be involved in the village discussion meeting is the children of the country or indigenous people, while the immigrant population is not involved and this happens that the migrant community does not want to be involved in participating in the development of their village (Toya \& Skidmore, 2007).

In addition, the researchers identified several obstacles to community participation or community involvement in the development process, including First, the condition of Waiheru Village still shows that the village government essentially still has excellent authority as well as being a source of legitimacy and has a very traditional role in the decision-making process. (decision-making process). Second, there are still many and classified as the majority; the people in this village show a weak level of community political knowledge, which results in people not understanding a village development planning process that follows village needs (Deeds \& Hill, 1996). The people do not strictly monitor community expectations according to their rights and obligations as citizens. Villagers and citizens. Third, the lack of openness of the village government and its institutions to the community, the absorption capacity of the aspirations of village institutions, and the openness of public space (public space) have not been optimal so that the empowerment of local communities related to their participation is still not mobilized (Blomström \& Sjöholm, 1999).

The discourse of community participation development has comprehensive and popular echoes (Saijo \& Yamato, 1999). The idea of participatory development departs from objective reality, which refers to the unequal structural conditions in power allocation and distribution of access to community resources (Sutoro, 2004). In addition, according to Tarigan (2005), the idea of development in its interventionist trend today began to develop at the end of the second world war, as a new vision full of hope against the backdrop of the bitter experience of war the unfolding process of decolonization. The opinion above implies that planned development is appropriate to be applied to developing countries.

According to Siagian (1991), the development itself is "an effort or series of planned growth and change efforts carried out consciously by a nation, state, and government, towards modernity in a series of national development." The regional autonomy law gives authority to districts and cities based on the principle of decentralization in realizing broad, accurate, and responsible autonomy (Kansil, 2006). The development paradigm that occurred in Indonesia experienced a long journey; in the era of the New Order government, the development process was carried out with a top-down approach with a centralized system, it was not successful in the social and political fields, although in the economic field it was pretty encouraging. 
2 Materials and Methods

This study was done in a qualitative technique (Bungin, 2001; Sgier, 2012). Qualitative research is research that is intended to understand the phenomenon of what is experienced by the subjects, such as behavior, perception, motivation, action, and others, holistically and by way of description in the form of words and language, in a particular natural context by utilizing various scientific methods (Sanapiah, 1995). The research method dramatically affects the achievement or failure of the objectives proposed in a paper. This study uses a qualitative descriptive approach. Through qualitative descriptive research, researchers try to describe events and events that are the center of attention without giving special treatment to these events - by doing some initial steps, namely the existence of a problem, then determining the type of information needed, determining the procedure for collecting data through observation or observation, processing data or data information and then concluding.

\section{Results and Discussions}

\section{Availability of information technology support}

The main problems proposed in this study are what factors affect the Effective Implementation of the Village Development Plan Deliberation (Musrembang) in Waiheru Village, TA Baguala District, Ambon City?. To answer these problems empirically, the author conducted field research to collect several data, which will then be processed and analyzed to describe what factors are the most dominant in influencing the effectiveness of the implementation of Musrembangdes in Waiheru Village (Beasley et al., 2005).

After the data is obtained, it is then reduced and selected against data from various instruments that have been previously provided, and it always focuses attention on the problems faced and the research objectives to be achieved. For this reason, the respondents' answers after being analyzed qualitatively by calculating the percentage of alternative answers given by respondents with the help of a frequency table. The results of these calculations are then calculated the average percentage value based on the respondents' answers to each question from each indicator so that conclusions can be made on determining which factors significantly affect the effectiveness of the implementation of the Musrembangdes in Waiheru Village among the four factors that have been determined as indicators of this research.

Based on this description, the following will be presented an overview of the research results and their discussion successively through various indicators. It will then be presented successively an overview of the research results and their discussion through the various indicators above, including the following:

\section{Harmonization of village government institutions with the community}

Every organization in one country, whether a government organization or a commercial organization, and even a social organization, is an inseparable part of the state, nation, and society concerned. Various organizations within the government create and work to serve the public interest. In this regard, every organization is always a subsystem of this country, nation, and society as a whole (Siagian, 1991). Since various organizations are an integral part of society as a whole, it is logical to say that the values and rules that exist and apply in society as a whole are consistently upheld by the government through the implementation of its duties and responsibilities to improve the welfare of the community (Zhu et al., 2008). A new paradigm of public administration emerged by formulating a series of ideals and practices related to using specific values and norms in the implementation of public service accountability (Herizal et al., 2020).

Village government organizations, as public organizations in terms of the context of state administration, have the task of implementing or implementing public policies, which existing village government officials and officials carry out, and there is no profit-seeking orientation. This follows the task of state administration which is to provide services to the public, trying to fulfill public interests (Sugandha, 1992).

For this reason, the task of the bureaucracy, in this case, the village government, is to carry out public policies that have been outlined by the holders of power who set policies. The longer the village government will face routine tasks of serving the community. In carrying out their duties, village government officials will refer to the duties, functions, and authorities given by the sub-district, district/city governments. This means that any action about duties must not exceed the existing authority.

Latuconsina, N., Khairunnisa, A., \& Tehuayo, J. (2022). Factors affecting the implementation of the village development plan deliberation (Musrembang) in Waeheru Village, Teluk Ambon District, Ambon City. International Research Journal of Management, IT and Social Sciences, 9(1), 181-192. https://doi.org/10.21744/irjmis.v9n1.2041 
Village Government Organizations are public organizations responsible for services to the community. Public service in this study is a term that describes the form and type of government service (public sector) to the community or individuals based on public interest. This service refers to fulfilling some of the community's basic needs, such as health, education, public transportation, and others. While the public services referred to in this study are the services provided by the village government to the community in the form of administrative services, all of which are closely related to the responsibility of the village government in the field of development. Empowerment is carried out to encourage the independence of village communities in developing potential local development (La Suhu \& Wance, 2019).

Empirically in Indonesia, many public services received by the community begin and end at the village level. The types and variations of village government organizations' services vary, ranging from ID Card services, family cards, recommendation letters of good conduct, land certification, and others. In addition to these service tasks, the government is responsible for village development services. Therefore, efforts to improve service performance in the field of village development should be directed following the community's needs for public facilities that are considered relevant to developments and progress in the field of development.

Sutoro (2004), states that development is carried out in the context of a fair balance between the government and village communities. The government must provide infrastructure, provide guidance and supervision, while the rest is left to the ability of the village community itself. The statement above shows that the village community's development is mainly borne as the primary development actors. This illustrates that community participation in development is a non-negotiable necessity because to carry out village development, community participation in village development is very important, but if the development is planned or decided by the village government to be implemented, it shows the aspirations of the community (Rahmiyati et al., 2021). Or interests in it.

The expected contribution of participation in development should be given continuously. Because development is for the community's welfare, community participation in development does not have to be forced but must come from the people's awareness. Tjokrowinoto (1996), Participation is given because of the encouragement of shared awareness and responsibility for the development. Participation given with just an appreciation because of hidden presumptions will have other effects if not solely driven by religious spirit or calling (Martini, 2020).

Participation, as referred to, may vary in the form of thoughts, objects, or energy. This is detailed by Ndraha (1984), in his expression, the burden of physical development includes Cost, labor, time, attendance, building materials, land, tools, and others. However, all this can be achieved if the village government can build relationships with the community in a harmonious atmosphere. Of course, this effort is not as easy as imagined because the harmonious relationship that occurs needs to start with the seriousness of the village government towards the various interests of the community in the existing village development plan so that the community will be encouraged and willing to voluntarily participate in various development activities that take place in their village. Furthermore, to find out how far the responses given by respondents are related to indicators of harmonization of village government institutions with the community, a detailed description will be presented in the following table:

Table 1

Respondents' responses to indicators harmonization of village government institutions with the community

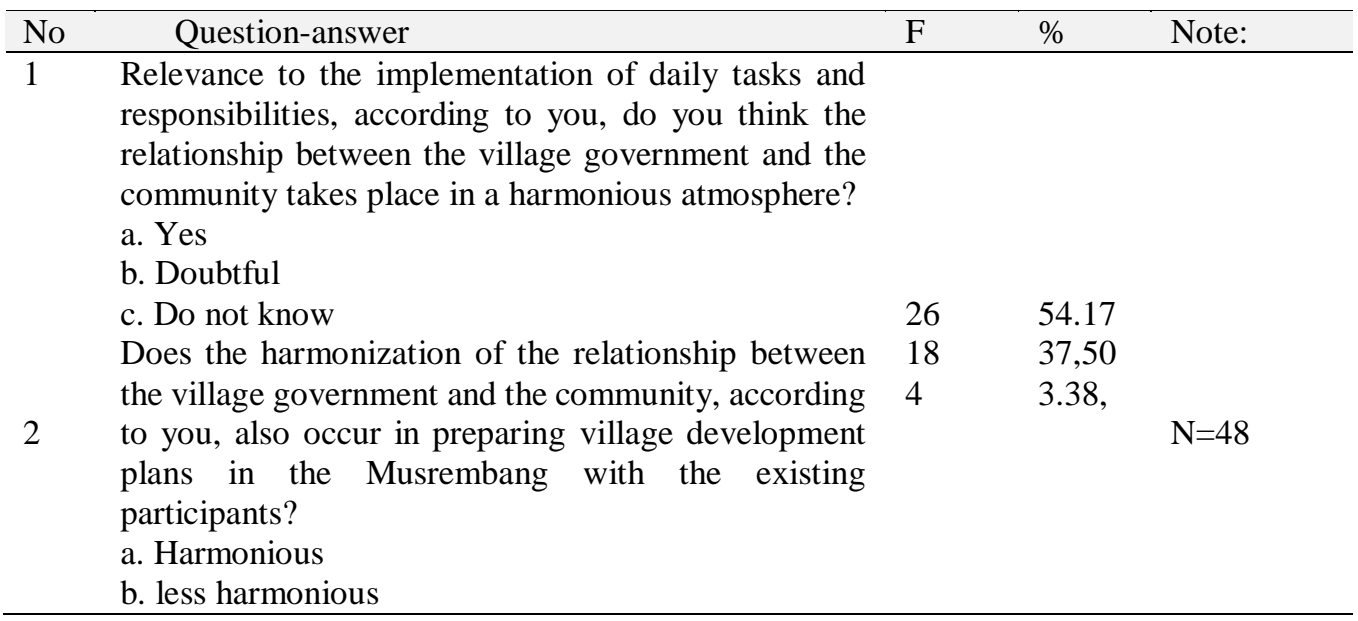


c. Not at all

In your opinion, do you think that Musrembang, in discussing the village development plan, can take place democratically so that all participants have the

20 15 41.67 31.25

3 same opportunity to express their thoughts?
a. Democratic
b. Less democratic
c. undemocratic

\begin{tabular}{lll} 
& 22 & 45.83 \\
& 14 & 29.17 \\
& 12 & 25.00 \\
\hline
\end{tabular}

Data Source: Field Research Results, 2021

The distribution of percentages based on the responses of respondents as shown in the table above can be described as follows:

Regarding the first question, 26 respondents $(54.17 \%)$ said that the relationship between the implementation of daily tasks and responsibilities, the village government, and its community took place in a harmonious atmosphere. As many as 18 people $(37.50 \%)$ said their doubts about this problem, and the remaining as many as four respondents $(3.38 \%)$ said they did not know at all.

The relevance to the second question is whether the harmonization of the relationship between the village government and the community also occurs in preparing the village development plan (Musrembang) with the existing participants? Showed as many as 20 people $(41.67 \%)$ said that it was harmonious, and as many as 15 other people (31.25\%) said it was less harmonious, while the remaining 13 people $(27.08 \%)$ said it was not harmonious at all.

As for the Musrembang in discussing the village development plan can take place democratically so that all participants have the same opportunity to express their thoughts? Twenty-two respondents $(45.83 \%)$ said that the Musrembang held could democratically. As many as 14 people others $(29.17 \%)$ said it was less democratic. While the remaining 12 people $(25.00 \%)$ said, they were not democratic.

From the results of the discussion of respondents' answers to the three questions regarding indicators of the establishment of a harmonious dynamic atmosphere between the village government and the community both in their daily activities while carrying out their duties and responsibilities as well as in the implementation of Musrembang, it shows that the harmonization that has occurred has not been established as expected. This assumption is also supported by the average percentage of respondents' answers with a tendency to qualify is less than $45 \%$.

\section{Providing community opportunities in Musrembangdes}

The use of a policy, including the policy on the use of human resources in government organizations, must consider the concept of sustainable development ("sustainable development"). According to Saputra (2020), sustainable development is defined as development that can meet the needs of the present without compromising the ability of future generations to meet their needs. More operationally, Beach et al. (1984), defines "sustainable development" as the ability of development projects (activities) to create sufficient "net surplus" to be input for further development. Therefore, the problem of coordination in the utilization of this policy is essential to ensure the achievement of its implementation objectives.

Furthermore, by James D. Mooney, coordination is an effort to regularly achieve group efforts and unity of action to achieve a common goal. Therefore, coordination is essential in any organization, including government organizations at the village level that have pretty complex tasks and responsibilities. In carrying out their authority in government duties, development, and community development, the village government is directly related to the community. For this reason, the urgency of coordination here is to achieve convenience in producing a genuinely aspirational village development plan because the community is directly involved in the Village Development Plan Deliberation (Musrembang).

Coordination is intended to prepare the village development plan becomes aspirational, and in determining the plan as a village decision, it becomes more democratic and can run or be completed on time. The relationship between joint efforts coordinated by the village government can be maintained to pursue common goals (Sutarto, 1980). In addition,

Latuconsina, N., Khairunnisa, A., \& Tehuayo, J. (2022). Factors affecting the implementation of the village development plan deliberation (Musrembang) in Waeheru Village, Teluk Ambon District, Ambon City. International Research Journal of Management, IT and Social Sciences, 9(1), 181-192. https://doi.org/10.21744/irjmis.v9n1.2041 
by coordinating the cooperation between the government and its people in implementing specific tasks, there is mutual understanding, complementarity, assistance, and complementarity. Thus, through effective coordination, it will be beneficial in integrating goals and activities in separate units or functional areas of an organization to achieve organizational goals effectively and avoid the jealousy that occurs.

So important is the issue of coordination in the implementation of a government policy, according to Handoko \& Tjiptono (1996), explaining that the basic mechanisms of coordination that can be used as a reference in work are: 1) Managerial hierarchy; Chain of command, the flow of information and work, formal authority, the precise relationship of responsibility and accountability and carried out with proper direction. 2) Rules and Procedures; They are decisions made from above to handle routine activities, so they can also be an efficient tool for routine coordination and supervision. Furthermore, to find out respondents' responses related to the indicators of providing community opportunities in the village development planning meeting, in detail it can be seen as follows;

Table 2

Respondents' responses to indicators providing community opportunities in the community discussion

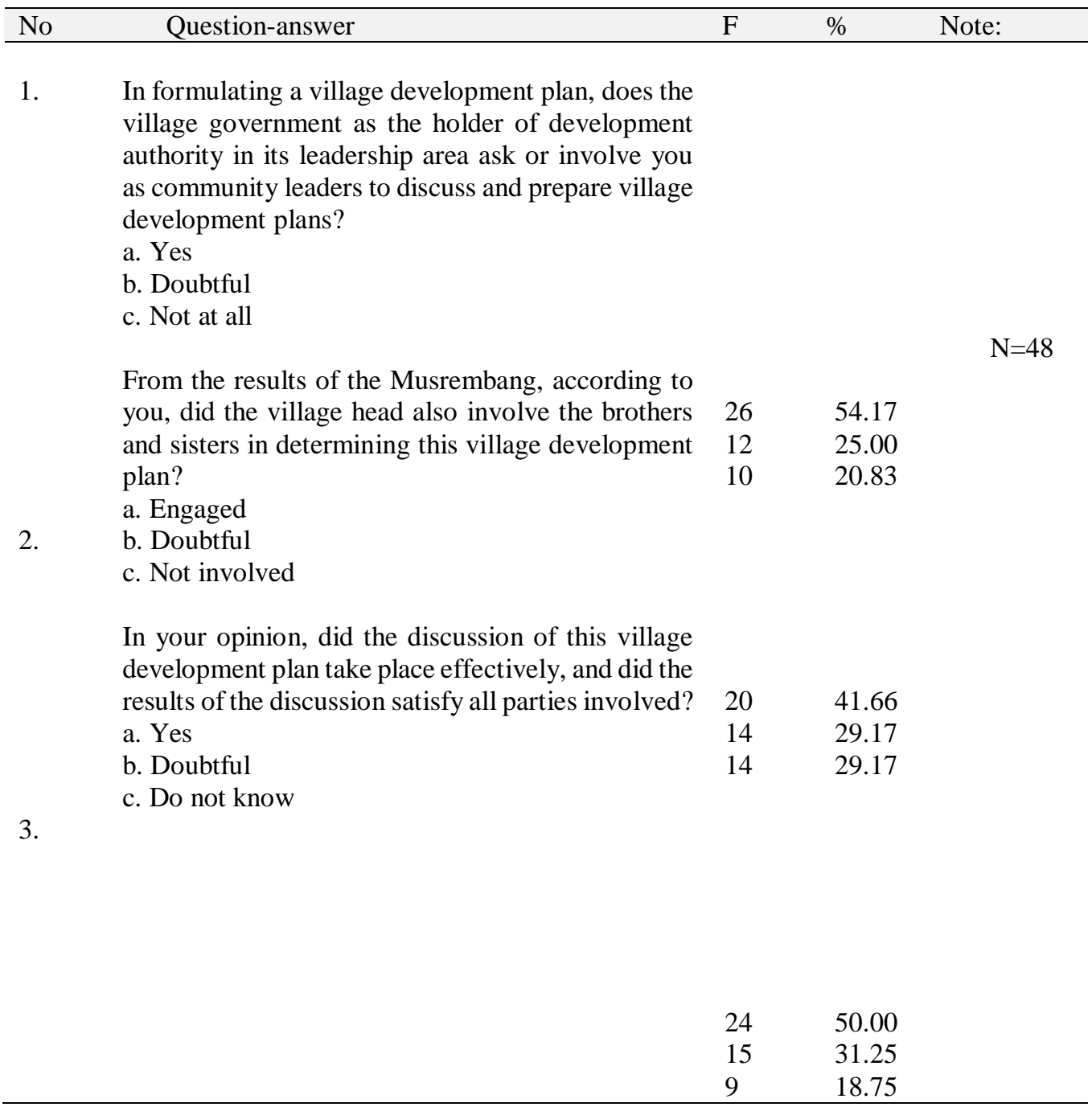

Data Source: Field Research Results, 2021

From the distribution of the percentage of respondents' responses seen in the table above, it can be described as follows: 
To adjust the desires and needs of the community in various village development programs, does the village government as the holder of development authority in its leadership area ask or involve relatives as community leaders to be involved in discussing and preparing village development plans? Showed that as many as 26 respondents $(54.17 \%)$ said that the village government asked or involved community leaders to be involved in discussing and preparing village development plans, and as many as 12 people $(25.00 \%)$ said they had doubts about this problem while the remaining ten people (20.83\%) said they did not know at all about this problem.

What is the relevance to whether the village head also involves the brothers and sisters in determining this village development plan? Seen as many as 20 respondents $(41.66 \%)$ said that the village head also involved relatives in the determination of this village development plan, and as many as 14 people $(29.17 \%)$ said they had doubts about this issue. Meanwhile, as many as 14 people $(29.17 \%)$ said they were not involved at all.

Meanwhile, regarding whether the discussion of this village development plan took place effectively and the discussion results were satisfactory to all parties involved, responses were obtained from 24 respondents (50.00\%) saying that the 'musrembang' carried out could take place effectively. The results of the discussion were satisfactory to all parties. Involved in it, and as many as 15 other people (31.25\%) said they were doubtful about the effectiveness and the discussion results were satisfactory for all parties involved in it. While the remaining nine people (18.75\%) said, they did not know at all.

The variety of responses given by respondents to several existing questions can be emphasized that although the development planning that the Waiheru Village government has designed is always taking into account the interests and needs of the community, in the 'musrembang', the community is represented by community leaders and RT heads is less involved. even though the village government has requested it.

\section{Democratization in expressing aspirations as needed}

Etymologically, participation comes from the English " participation," translated in the Big Indonesian Dictionary as participation in an activity, participation, participation. The meaning of participation is very diverse; everyone can define participation according to the believed point of view. Briyant et al. (1987), argue that participation is an attitude of openness and other feelings or participation means serious attention to the differences or changes produced by a project about people's lives or it is also said that participation is awareness of the contributions that the parties can make for an activity.

Werther Jr \& Davis (1985), express participation as an individual's mental and emotional involvement in group situations that require him to contribute to achieving group or organizational goals and share responsibilities with them. Then Ranuh et al. (1980), revealed that participation does not just arise; community participation will arise if there is a condition of mutual trust between officers and the existing community, an invitation for the community to participate from the beginning of planning activities that are felt by the community and there is an example from community leaders.

When everyone has their understanding of participation, there will be some differences in the concept of participation. The concept of participation that the government has designed has led to many polemics. According to Sutoro (2004), first, the government tends to place the community as the object of policy; the community does not need to do important things to follow the policies that have been set. Second, participation is always interpreted as community involvement in government policies, whether the involvement is based on awareness or is still limited to mobilization from the government. Third, community involvement or participation in the policies taken. When in fact, the community only plays a passive role as an object of socialization and information, this is where a leader who can encourage and motivate them is needed, for that a good information leader is needed.

According to Juliantoro (2002), the substance of participation in a government system where no policies are taken without the people's consent, while the primary direction is the empowerment process. First, participation will enable the people to organize themselves independently and thus make it easier for the people to face difficult situations and resist adverse tendencies. Second, participation is a concrete mirror of opportunities for the expression of aspirations and ways to fight, but more importantly, participation becomes a kind of guarantee that the people's interests are not ignored. Third, the problems of development dynamics will be overcome with participation.

Furthermore, according to Sutoro (2004), community participation in governance understands the relationship between the state and the government. The essence of the relationship includes: 1) The community is not a servant or client but a citizen (citizen). 2) The community is not a governed position but a planning partner in managing government and development. 3) Participation is not a gift from the government but is a right as a citizen. 4) Society is not a passive object of government policy beneficiaries but an active or subject to determine policy.

Latuconsina, N., Khairunnisa, A., \& Tehuayo, J. (2022). Factors affecting the implementation of the village development plan deliberation (Musrembang) in Waeheru Village, Teluk Ambon District, Ambon City. International Research Journal of Management, IT and Social Sciences, 9(1), 181-192. https://doi.org/10.21744/irjmis.v9n1.2041 
Based on the various descriptions above, it can be emphasized that participation should be born from below and not born out of mobilization by the government because then participation that occurs will be based on sincerity or voluntary conditions born of awareness about the importance of development activities that are being and will be implemented, only for the sake of society itself. On the other hand, participation is limited to physical community involvement in various activities and includes community involvement in preparing and discussing development plans or participation in conveying ideas or ideas that grow and develop during society. Relevant to this problem, the following will the author convey the responses of respondents related to democratization indicators in conveying aspirations as needed as follows:

Table 3

Respondents' responses to indicators democratization in conveying aspirations as needed

\begin{tabular}{|c|c|c|c|c|}
\hline No. & Question-answer & $\mathrm{F}$ & $\%$ & Note: \\
\hline 1. & $\begin{array}{l}\text { In your opinion, do you think that in a village } \\
\text { development plan meeting or deliberation } \\
\text { (Musrembangdes), the village head allows you } \\
\text { to convey development ideas/ideas following } \\
\text { the aspirations that develop amid the } \\
\text { community? } \\
\text { a. Give } \\
\text { b. Less given } \\
\text { c. Not given }\end{array}$ & & & $\mathrm{N}=48$ \\
\hline 2. & $\begin{array}{l}\text { In your opinion, do all the ideas/ideas } \\
\text { submitted are always given rational } \\
\text { consideration by the village government if } \\
\text { they are included or not included in the } \\
\text { existing village development plan? } \\
\text { a. Yes } \\
\text { b. Doubtful } \\
\text { c. Do not know }\end{array}$ & $\begin{array}{l}24 \\
18 \\
6\end{array}$ & $\begin{array}{l}50.00 \\
37,5012,50\end{array}$ & \\
\hline 3. & $\begin{array}{l}\text { In your opinion, can all the ideas/ideas } \\
\text { submitted be included as a village } \\
\text { development plan in the Musrembang? } \\
\text { a. Entered } \\
\text { b. Doubtful } \\
\text { c. Not entered }\end{array}$ & $\begin{array}{l}19 \\
18 \\
11\end{array}$ & $\begin{array}{l}43.75 \\
31.25 \\
25.00\end{array}$ & \\
\hline
\end{tabular}

Data Source: Field Research Results, 2021

The distribution of percentage distribution based on respondents' responses, as shown in the table above, can be described as follows:

Regarding the first question, 24 people $(50.00 \%)$ of respondents said that the village head always provided opportunities for brothers and sisters to convey development ideas/ideas following the aspirations that developed amid the community. As many as 18 people (37 .50\%) said that they were not allowed to address this problem and the 
remaining six respondents (12.50\%) said they were not allowed to convey development ideas/ideas following the aspirations that developed during society in musrembang held.

The relevance to the second question is whether the village government always gives all ideas/ideas submitted rational consideration if they are included or not included in the existing village development plan? Showed as many as 19 people (39.58\%) said yes that all ideas/ideas submitted were always given rational consideration by the village government if they were included or not included in the existing village development plan. As many as 18 other people $(37.50 \%)$ said they had doubts about this problem, while the remaining 11 people $(22.92 \%)$ said they did not know about it.

As for whether all submitted ideas/ideas can be included as a village development plan in the Musrembang?, 21 respondents $(43.75 \%)$ said that all submitted ideas/ideas could be included as village development plans, and as many as 15 other people $(31.25 \%)$ said they were doubtful that all the ideas submitted could be included as a village development plan, while the remaining 12 people $(25.00 \%)$ said they were not included at all.

From the results of the discussion of respondents' answers to the three questions about the indicators of providing opportunities to convey ideas/ideas, it shows that most of the respondents said that most of the aspirations that developed during the community even became strategic needs for the benefit of the community which was not included in this village development plan, or In other words, the development plan in Waiheru Village is still less aspirational. This is said so because it is based on respondents' answers where the percentage tends to lead to less accommodation of ideas and ideas in existing development plans. The lack or lack of accommodation of these ideas and ideas can be seen from the lack of opportunities given by the village government to elements of community leaders to speak and express opinions in the Musrembangdes held in this village.

\section{Conclusion}

Based on the results of data collection and analysis of the four indicators in this study, it can be concluded as follows:

- Even though the development planning that the Waiheru Village government has designed is always taking into account the interests and needs of the community, in the musrembang, the community represented by community leaders and RT heads is not involved in it even though the village government has requested it.

- From the results of the discussion of respondents' answers to the three questions regarding indicators of the establishment of a harmonious dynamic atmosphere between the village government and the community both in their daily activities while carrying out their duties and responsibilities as well as in the implementation of Musrembang, it shows that the harmonization that has occurred has not been established as expected. This assumption is also supported by the average percentage of respondents' answers with a tendency to qualify is less than $50 \%$.

- The indicator of providing opportunities to convey ideas/ideas shows that most of the respondents said that most of the aspirations that developed during the community even became strategic needs for the benefit of the community, which was not included in this village development plan or other words the development plan in Waiheru Village was still lacking. Aspirational. This is said so because it is based on respondents' answers where the percentage tends to lead to less accommodation of ideas and ideas in existing development plans. The lack or lack of accommodation of these ideas and ideas can be seen from the lack of opportunities given by the village government to elements of community leaders to speak and express opinions in the Musrembangdes held in this village. Thus, it is clear that this indicator can be categorized as having a relatively low influence qualification as one of the factors in measuring the variables of this research.

\section{Conflict of interest statement}

The authors declared that they have no competing interests.

Statement of authorship

The authors have a responsibility for the conception and design of the study. The authors have approved the final article.

Latuconsina, N., Khairunnisa, A., \& Tehuayo, J. (2022). Factors affecting the implementation of the village development plan deliberation (Musrembang) in Waeheru Village, Teluk Ambon District, Ambon City. International Research Journal of Management, IT and Social Sciences, 9(1), 181-192. https://doi.org/10.21744/irjmis.v9n1.2041 
Acknowledgments

Thanks, we convey to the Government Science Lecturer Pattimura University, who have provided input and support so that this research could be carried out to completion 


\section{References}

Beach, R. M., Carner, G. R., \& Turnipseed, S. G. (1984). Field efficacy and persistence of a nuclear polyhedrosis virus of the velvetbean caterpillar in soybeans. Journal of Agricultural Entomology, 1(3), 296-304.

Beasley, M. S., Clune, R., \& Hermanson, D. R. (2005). Enterprise risk management: An empirical analysis of factors associated with the extent of implementation. Journal of accounting and public policy, 24(6), 521-531. https://doi.org/10.1016/j.jaccpubpol.2005.10.001

Blomström, M., \& Sjöholm, F. (1999). Technology transfer and spillovers: Does local participation with multinationals matter?. European economic review, 43(4-6), 915-923. https://doi.org/10.1016/S0014-2921(98)00104-4

Briyant, C., Hagul, P., Simatupang, R. L., \& White, L. G. (1987). Manajemen pembangunan: untuk negara berkembang. LP3ES.

Bungin, B. (2001). Metodologi penelitian kualitatif.

Deeds, D. L., \& Hill, C. W. (1996). Strategic alliances and the rate of new product development: An empirical study of entrepreneurial biotechnology firms. Journal of business venturing, 11(1), 41-55. https://doi.org/10.1016/08839026(95)00087-9

Handoko, H., \& Tjiptono, F. (1996). Kepemimpinan transformasional dan pemberdayaan. Journal of Indonesian Economy and Business, 11(1).

Herizal, H., Mukhrijal, M., \& Wance, M. (2020). Pendekatan akuntabilitas pelayanan publik dalam mengikuti perubahan paradigma baru administrasi publik. Journal of Governance and Social Policy, 1(1).

Hidayat, W. (2003). Kebijakan \& manajemen pembangunan partisipatif. Yayasan Pembaruan Administrasi Publik Indonesia.

Juliantoro, D. (2002). Negara demokrasi untuk Indonesia. Pondok Edukasi.

Kansil. (2006). Membangun Pedesaan Partisipatif. UNHAS, Makassar.

La Suhu, B., \& Wance, M. (2019). Pemberdayaan Masyarakat Petani Rumput Laut Di Kabupaten Halmahera Selatan (Studi Desa Mano Kecamatan Obi Selatan). JOURNAL OF GOVERNMENT (Kajian Manajemen Pemerintahan dan Otonomi Daerah), 4(2), 156-172.

Martini, N. K. A. (2020). Community participation in Blangsinga tourism village development. International Research Journal of Management, IT and Social Sciences, 7(3), 91-97. https://doi.org/10.21744/irjmis.v7n3.922

Ndraha, T. (1984). Pembangunan desa dan administrasi pemerintahan desa. Yayasan Karya Dharma, Institut Ilmu Pemerintahan.

Pickett, S. T., Cadenasso, M. L., \& Grove, J. M. (2004). Resilient cities: meaning, models, and metaphor for integrating the ecological, socio-economic, and planning realms. Landscape and urban planning, 69(4), 369-384. https://doi.org/10.1016/j.landurbplan.2003.10.035

Rahmiyati, N., Andayani, S., \& Indartuti, E. (2021). Community participation in the development of the tourism area of Segunung indigenous village in Carangwulung village, Wonosalam district, Jombang regency. International Research Journal of Management, IT and Social Sciences, 8(4), 291-302. https://doi.org/10.21744/irjmis.v8n4.1889

Ranuh, I. N. G., Sarwono, E., \& Hardjadinata, D. (1980). Study on the usefulness of clinical manifestations in the diagnosis of neonatal sepsis.

Saijo, T., \& Yamato, T. (1999). A voluntary participation game with a non-excludable public good. Journal of Economic Theory, 84(2), 227-242. https://doi.org/10.1006/jeth.1998.2476

Sanapiah, F. (1995). Format-format Penelitian Sosial, Dasar-dasar dan Aplikasi. Jakarta: Rajawali pers.

Saputra, R. (2020). Development of Creative Industries as Regional Leaders in National Tourism Efforts Based on Geographical Indications. BESTUUR, 8(2), 108-120.

Sgier, L. (2012). Qualitative data analysis. An Initiat. Gebert Ruf Stift, 19, 19-21.

Siagian, S. P. (1991). Teori dan praktek kepemimpinan.

Spash, C. L. (2007). Deliberative monetary valuation (DMV): Issues in combining economic and political processes to value environmental change. Ecological economics, 63(4), 690-699. https://doi.org/10.1016/j.ecolecon.2007.02.014

Sugandha, D. (1992). Pengantar Administrasi Negara. CV. Intermedia.

Sutarto. (1980). Pemberdayaan Pengembangan Masyarakat dan Intervensi Komunitas. UI, Jakarta.

Sutoro, E. (2004). Pemberdayaan Kaum Marginal.

Tarigan, M. (2005). Perencanaan dan Evaluasi. Bina Aksara, Jakarta.

Tjokrowinoto, M. (1996). Pembangunan: Dilema dan tantangan. Pustaka Pelajar.

Latuconsina, N., Khairunnisa, A., \& Tehuayo, J. (2022). Factors affecting the implementation of the village development plan deliberation (Musrembang) in Waeheru Village, Teluk Ambon District, Ambon City. International Research Journal of Management, IT and Social Sciences, 9(1), 181-192. https://doi.org/10.21744/irjmis.v9n1.2041 
Toya, H., \& Skidmore, M. (2007). Economic development and the impacts of natural disasters. Economics letters, 94(1), 20-25. https://doi.org/10.1016/j.econlet.2006.06.020

Tuanaya, W., \& Wance, M. (2021). Wayame village government partnership pattern in handling COVID 19 in Ambon city. Turkish Journal of Physiotherapy and Rehabilitation, 32(3).

Van Lier, H. N. (1998). The role of land use planning in sustainable rural systems. Landscape and Urban Planning, 41(2), 83-91. https://doi.org/10.1016/S0169-2046(97)00061-3

Werther Jr, W. B., \& Davis, K. (1985). Personnel management and human resources.

Wilson, M. A., \& Howarth, R. B. (2002). Discourse-based valuation of ecosystem services: establishing fair outcomes through group deliberation. Ecological economics, 41(3), 431-443. https://doi.org/10.1016/S0921-8009(02)000927

Zhu, Q., Sarkis, J., \& Lai, K. H. (2008). Confirmation of a measurement model for green supply chain management practices implementation. International journal of production economics, 111(2), 261-273. https://doi.org/10.1016/j.ijpe.2006.11.029 